\title{
Grammtical Code Switching in The English Department Proposal Seminar
}

\author{
Rakhmat Wahyudin Sagala ${ }^{1}$, Tri Indah Rezeki ${ }^{2}$ \\ ${ }^{1}$ Universitas Muhammadiyah Sumatera Utara \\ ${ }^{2}$ STKIP Budidaya Binjai \\ rakhmatwahyudin@umsu.ac.id
}

\begin{abstract}
The fundamental characteristics of the lecturers and the students in the English Department should use English. Lack of English competence is widely considered to be the major cause of code switching. The aim of our work to broaden current knowledge of the phenomenon of grammatical code switching in the English Department proposal seminar at STKIP Budidaya Binjai. This study applied descriptive qualitative research with the data from the utterances of the lecturers and the students during the process of proposal seminar. The data were obtained from observation, interview, and field note. Grammatical code switching in the English Department proposal seminar were tag code switching consisted of 12 utterances, inter-sentential code switching consisted of 15 utterances, intra-sentential code switching consisted of 19 utterances, proper noun and noun phrase consisted of 7 utterances, negative words consisted of 4 utterances, languages similarity consisted of 11 utterances and discourse marker consisted of 16 utterances. It can be concluded that grammatical code switching occurs in the English Department proposal seminar process
\end{abstract}

Keywords: code switching; classification of code switching; grammatical code switching

\section{Introduction}

There are three kinds of language choice in sociolinguistics study namely code switching, code mixing, and variation within the same language [1]. This study focuses on the phenomenon of code switching which occurs in the English department proposal seminar. Normally, the process of proposal seminar in English department should use English in their communication. In fact, the researchers found that lecturers and students switched their languages by using two languages namely English and Indonesia. This phenomenon can be called as code switching. Code switching is used to fulfill sense of the speaker. When the speaker cannot convey his/her message by using one language, the speaker needs to change the language to be more understood [2]. Code switching can occur in the daily conversation which is used by the speakers and it can occur between the sentences in the conversation and can occurs within the sentences. Code switching is one form of language use by bilinguals i.e. the use of more than one language by choosing one of language code adjusted to the circumstances [2]. In other words, code switching is the phenomenon of language use because of the situation changing [3]. In addition, code switching not only occurs among the languages, but also among the kinds or language styles in one language such as code switching between Indonesia and English [4].

Code switching can be divided into two classifications. First, grammatical is based on switching in sentences or utterances. Second, contextual is based on reasons why code switching occurs. Generally, code switching is often used in educational environment include in university especially in the English Department. This is because English is not first language for the lecturers and the students. Therefore, code switching is used to make the communication easier which relate to the whole activities in the English Department. Reasons for code switching such as lack of facility, lack of register competence, semantic significance, to address different audience, to show identity with a group, to emphasize a 
point, mood of the speaker, habitual expressions, pragmatic reasons and to attract attention [5]. This study was important to be done because the phenomenon of code switching was often found in English classroom. Some scientists have done their research about code switching in the classroom. The observation of code switching shows complex learning and communicative strategies, and emphasizes the need to better understand these strategies and their role in the learning process [6].

Code switching is a widely observed phenomenon especially seen in multilingual and multicultural communities. In ELT classrooms, code switching comes into use either in the teachers' or the students' discourse. Although it is not favored by many educators, one should have at least an understanding of the functions of switching between the native language and the foreign language and its underlying reasons [7]. Another finding was also found in teachers' code-switching and learners' learning success. Learners also showed favorable support for future code-switching in the English classrooms. It is strongly believed that teachers' code-switching is an effective teaching strategy when dealing with low English proficient learners [8].

This study focused on the process of proposal seminar in English department. Based on observation and interviews which were done by the researchers, the lecturers tend to use code switching to help the students to keep the communication is going on. Meanwhile the students tend to use code switching because of the lack of vocabulary and their knowledge about the material in the proposal seminar. The purpose of this study is to analyze grammatical code switching which occurs in the English Department proposal seminar at STKIP Budidaya Binjai. The scopes of this study is analysis of kinds of grammatical code switching in the English Department proposal seminar process.

\section{Method}

This study applied descriptive qualitative research which is the research procedures obtained descriptive data in written or spoken form from the people and their behavior which is being observed [9]. The subject research were lecturers and students in the English Department proposal seminar at STKIP Budidaya Binjai. The data were taken from conversation of the lecturers and the students during the process of proposal seminar. In collected the data, researchers used instruments such as observation, interviews, and field note [10].

\section{Result and Discussion}

\subsection{Grammatical Code Switching Analysis}

There are seven types of code switching grammatical namely Tag code-switching; a bilingual switches short expression in his utterance, Inter-Sentential code switching; a bilingual switches code between sentences, Intra-Sentential code switching; a bilingual switches code within sentences, Proper Noun; a bilingual switches the name of people, places or specific register and noun phrase; a phrase consisted of noun, Negative Words; a bilingual switches non-standard negative words such as "nggak" or "ndak", Languages Similarity; a bilingual switches a word that has same meaning and same sound between languages and Discourse Marker; a bilingual switches discourse marker such as "kok", "kan", "lho", "anu", etc. [11].

The data showed that there are 84 utterances of lecturers and students in the proposal seminar process that contain grammatical code switching. Tag code switching consisted of 12 
utterances, inter-sentential consisted of 15 utterances, intra-sentential consisted of 19 utterances, proper noun and noun phrase consisted of 7 utterances, negative words consisted of 4 utterances, languages similarity consisted of 11 utterances and discourse marker consisted of 16 utterances.

These are some data examples which were taken from seminar proposal in English department at STKIP Budidaya Binjai.

1. The example of tag code switching analysis:

Lecturer : "Oh ya! Why do you do this research?"

Student : :Hmm, karena research ini penting untuk membantu siswa meningkatkan writing ability."

The word "oh $y a$ " and " $h m m$ " are tag code switching because the speaker switched short expression from different language.

2. The example of inter sentential code switching analysis:

Lecturer : "Apa kamu yakin? Do you think that multiple choice suitable to measure students' reading comprehension?"

Student : "I think yes mom. Karena yang mau dilihat kemampuan membacanya."

From the data, the speakers switched code between sentences. The lecturer used Indonesia language and then used English in the second sentence. In contrast, the student used English in her first sentence and then used Indonesia language in the next one.

3. The example of intra sentential code switching:

Lecturer : "Apa itu quantitative experiment?"

Student : "Membandingkan dua kelas experimental and control group."

From the data, the speakers switched code within sentences. The lecturer and the student combined Indonesia language and English in one sentence.

4. The example of proper noun/noun phrase analysis:

Student : "The population is kelas eleventh SMAN Bahorok."

The word "SMAN Bahorok" is a proper noun because it is a name of school or institution.

5. The example of negative words expression:

Student : "Yes, mom. Jadi kalau begitu multiple choice nggak bisa ya mom?"

The word "nggak" is slang word from "tidak" in Indonesia. The word "nggak" is a non-standard negative words.

6. The example of language similarity expression:

Student : "I think yes. Karena metode ini memudahkan siswa dalam menulis paragraf deskriptif."

The speakers used the same meaning and the same sound between Indonesia and English such as "paragraf" (Indonesia) - paragraph (English), "deskriptif" (Indonesia) descriptive (English)

7. The example of discourse marker expression:

Student : "Definition nya dibuat, ini kan teori yang harus kamu kerjakan." 
The speaker used "nya" and "kan" as discourse marker in his utterance.

\section{Conclusion}

Based on the discussions that have been described, it can be concluded that grammatical code switching is used by speakers in the English Department proposal seminar. In other words, lecturers and students used kinds of grammatical code switching namely tag code switching, inter-sentential, intra-sentential, proper noun/noun phrase, negative words, language similarity and discourse markers.

\section{Acknowledgement}

This study supported by SIMLIMTABMAS. Department of Research and Community Service (DRPM). Direktorat Jenderal Penguatan Riset dan Pengembangan. The Ministry of Research, Technology and Higher Education (Kemenristekdikti) according to research contract in 2018.

\section{References}

[1] Sumarsono. 2014. Sosiolinguistik. Yogyakarta: Pustaka Pelajar

[2] Hudson, Richard A. 1996. Sociolinguistics. Second edition. Cambridge University

[3] Chaer, Abdul dan Leoni Agustina. 2010. Sosiolinguistik. Jakarta: Rineka Cipta

[4] Chaer, Abdul. 2012. Linguistik Umum. Jakarta: Rineka Cipta.

[5] Malik, L. 1994. Socio-Linguistics: A study of code switching. Anmol Publication Pvt. Ltd: New Delhi.

[6] D. Moore, "Case Study Code Switching and Learning in the Classroom," International Journal of Bilingual Education and Bilingualism. Vol. 5, No.5, 2002, pp. 290-291

[7] O. Sert, "The Function of Code Switching in ELT Classrooms," The Internet TESL Journal. Vol. XI, No. 8, August 2005

[8] B. H. Ahmad, "Teachers' Code-Switching in Classroom Instructions for Low English Proficient Learners," English Language Teaching CCSE Journal. Vol. 2. No. 2, June 2009, pp. 52

[9] Moleong, Lexy J. 2012. Metodologi Penelitian Kualitatif. Bandung: Remaja Rosdakarya

[11] Miles \& Huberman. 1992. Analisis Data Kualitatif. Jakarta: UI-Press

[12] Jendra, Made Iwan Indrawan. 2010. Sociolinguistics: The Study of Societies' Languages. 